\title{
GENETIC RESOURCES OF FLAX IN LATVIA
}

\author{
Lubova Komlajeva, Aleksandrs Adamovičs \\ Latvia University of Agriculture, Liela Street 2, Jelgava, Latvia, LV 3001 \\ Ph.: +(371)28784059, e-mail: Lubasha_k@inbox.lv
}

\begin{abstract}
Flax is cultivated on small areas in Latvia. Flax gives dual-purpose production - fibre and seeds. Latvian flax has a high fibre and seed quality. The quantity of flax fibre and seed yield depends on many factors. Several qualitative and quantitative traits, such as technical stem length, resistance to lodging, vegetation period, yield of straw and seeds, fibre and oil content and quality were evaluated. For the further development of Latvian economy flax varieties and hybrids of Latvian origin are an important goal. Fibre flax varieties 'Blue di Riga', 'Priekuļu 665', 'Ošupes 30' and breeding lines 'S-64-17-93' and 'L11-11/11-94' are valuable material containing a qualitative and quantitative indicators of variety. 92 Latvian accessions of flax hybrids have been evaluated, and 12 accessions with the best seed and straw yield have been selected for further DNA analysis. This will simplify and accelerate the selection of new valuable hybrids that will provide particular advantages in agriculture. The genetic analysis of DNA determines the kinship and diversity of flax varieties and breeding lines which can be used further in flax breeding.
\end{abstract}

Key words: DNA, fibre, flax, genotype, oil.

\section{Introduction}

Flax (Linum usitatissimum L.) is an annual herbaceous plant with a steep footstalk. This is an important fibre and oil crop. Flax is mostly cultivated in the east part of Latvia. In the thirtieth year of the last century Latvia was one of the largest growers and exporters of flax in Europe. In Latvia the area of flax was less than 400-500 hectares during the last years, but once it was from 20000 to 80000 hectares. In 2001 flax area was about 1500 hectares, or by 13_percent less than in 1999. Total production compared to 1998 increased by 2.5 times. In 2000 from a hectare were harvested 3.35 tons of flax middling stem $[4,5,6,7,12]$.

One of the main problems there is the seed material luck in flax cultivation, and its purchasing from foreign countries is very expensive. Larger profits are necessary to purchase seed, but the state subsidizes $62 \%$ from payments. Growing of flax can be mechanized, but half of the work must be done manually. In 2001 in Latvia flax was grown by 72 farms, where the average size of the flax area was 10-20 hectares. The structure of flax area in 2001 according regions was following: 968 hectares of flax were sown in Eastern Latgale (Rezeknes and Ludzas district) (harvested 3409 tons of straw); 376 hectares - in South Latgale (Preilu, Daugavpils, Kraslavas district) (harvested 1195 tons); 145 hectares sown in a North-Eastern region of Latvia (Gulbenes, Aluksnes, Balvu district) (harvested 44 tons); 81 hectare - in North Vidzeme (Limbazu, Valmieras, Valkas, Cesu district) (harvested 168 tons); 10 hectares - in North Kurzeme (Ventspils, Talsu, Tukuma district) (none of ton was sold to a processing factory). There are four flax processing factories in Latvia - in Ludza, in Kraslava, in Rezekne and in Valmiera's district.

At least three tons of flax stem from one hectare must be harvested to keep profitable flax growing. Otherwise the money will be lost.

In 2008 and 2009 the weather during vegetation period was favourable for flax growing, but in Latvia the area of flax decrease during the last years. Flax is requested in the world. Jelgava's enterprise "Larelini", that processes flax straw into long fibre, sends products to the USA and Germany. But the short fibre, which is bought by flax factories, goes to Lithuania and from there further to France. 
In Latvia in the Ltd „Agricultural Science Centre of Latgale” the morphological research of many varieties of fibre flax and breeding lines was done. The best fibre is gained from flax, whose stem technical length is $60 \mathrm{~cm}$.

For the further development of Latvian economy flax varieties and breeding lines of Latvian origin are an important goal. There is a large value of flax seeds not only for human food necessities, but also for forage [1, 2, 3].

Flax resistance to diseases, flax with good fibre and seed quality grows in Latvian climatic conditions and can be widely used for the manufacture of fabrics, linseed oil extraction, pharmaceutical, paper industry, construction, motor factory, and elsewhere. It promotes flax processing businesses in Latvia. It is therefore very important to grow and retain the best of flax genetic resources of Latvian origin and create new varieties of flax, which are ecologically flexible and adapted to local agro-climatic conditions, and will be identified for specific uses $[6,7,8]$.

In the recent years, studying the site-specific and species within the plant genetic material, molecular markers method using primer pairs of PCR (Polymerase Chain Reaction) is applied; in result allele's combination describes appropriate variety of flax (RAPD-PCR) [8]. The aim of this research was to clarify the diversity of Latvian flax varieties and relationship between morphological, phenological, phytopathological parameters using molecular markers. Using biotechnology methods new genes are determined; regulating them better yields can be obtained $[9,10]$.

Now advanced technologies are used for the description of flax genomic, allowing to identify individual chromosomes with the morphological characteristics [11]. Studies show that the chromosomes of cultivated flax are very different from chromosomes of the wild species. Creation of the relationship between different flax varieties and obtaining a description of chromosomes simplifies and accelerates the discovering new valuable hybrids.

\section{Materials and methods}

The evaluation of 72 flax varieties and 20 breeding lines was done in this research (random block design, three replications). Accessions were compared with standard fiber flax variety 'Vega 2'.

Agriculturally important traits, such as technical stem length, resistance to lodging, duration of vegetation period, yield of straw and seeds, fibre and oil content were evaluated. The agricultural characteristic of soil at the site: sod podzolic sand loam with $\mathrm{pH}$ 6.4-7.0, phosphorus content $\mathrm{P}_{2} \mathrm{O}_{5}-130-145 \mathrm{mg} \mathrm{kg}{ }^{-1}$, potassium content $\mathrm{K}_{2} \mathrm{O}-118-124 \mathrm{mg} \mathrm{kg}^{-1}$ soil. In the spring after first soil cultivation the complex mineral fertilizers NPK 6-26-30 $(300 \mathrm{~kg}$ $\mathrm{ha}^{-1}$ ) were applied. Seeds were sown in May manually, seed rate -170 seeds on the $\mathrm{m}^{-1}$. The distance between rows was $10 \mathrm{~cm}$, sowing depth 2-3 cm. In the "fir tree" phase of the flax development $\mathrm{N}$ fertilizers at rate $15 \mathrm{~g} \mathrm{~m}^{-2}$ were applied.

The meteorological conditions_differently affected growth and development of flax during the growing period from 2007 to 2009 . The drought negatively affected germination of flax in spring.

Flax accessions were harvested in early yellow ripening phase. When the standards of flax were dry, flax was trashed with 'Eddi'. Flax straw yield was measured $\mathrm{g} \mathrm{m}^{-2}$. Seeds were cleaned with MLN sample cleaner; the yield of seed was weighed, and then re-calculated to the weight of $100 \%$ purity and $9 \%$ humidity. Oil content was determined by grain analyzer Infratec $1241 \mathrm{tm}$ with a special built-in machine for flax oil content in seed.

After flax morphological analysis 12 flax seed samples of the best qualitative and quantitative indices were selected to DNA analyse. Seed were sown, and for DNA genetic analysis six seedling of each variety were excluded.

To TE buffer shortly before distribution was joined B-merkaptoetanol in ratio 1:0,004. 
There was inserted raw material $(0.2 \mathrm{~g})$, joined $200 \mu$ 1.p. to made solution and $400 \mu$ lysine solution.

Flax samples were cut up to a homogeneous mass and placed in the $1.5 \mathrm{ml}$ Eppendorf micro test tubes, and they were incubated for 5 minutes in a $+65^{\circ} \mathrm{C}$ temperature. After the $600 \mu \mathrm{l}$ chloroform loaded in each tube, tubes were shaking in the centrifuge for 5 minutes (10000 $\mathrm{rpm})$. The solution of precipitation was prepared: mixed up $720 \mu \mathrm{l}$ of water with $80 \mu \mathrm{l}$ of precipitations.

After centrifuging supernatant and precipitations which contained DNS were placed to other Eppendorf micro test tubes and later were joined to $800 \mu \mathrm{l}$ made rein solution, mixed for 1-2 minutes at room temperature. Tubes were centrifuged for 5 minutes $(10000 \mathrm{rpm})$ till being liquid layer was fully separated. Precipitations were dissolved in $100 \mu 1.2 \mathrm{M} \mathrm{NaCl}$ solution till full decomposition. There was joined $4 \mu \mathrm{l}$ RNA solution $(0.1 \mathrm{mg} / \mathrm{ml})$ and maintained at $+37-40^{\circ} \mathrm{C}$ temperature for about 30 minutes. There was joined $300 \mu \mathrm{la} 96 \%$ ethyl alcohol into a solution, it was get cool to $+20^{\circ} \mathrm{C}$ and kept 20 minutes. Later tubes were centrifuged for 5 minutes (10000 rpm). After centrifuging ethyl alcohol was pour out and remains (substance with DNS) washed with $1 \mathrm{ml}+20^{\circ} \mathrm{C}$ temperature ethyl alcohol-water $70 \%$ solution.

Remains with DNS were fully suspended in solution (float free) and tubes were centrifuged for 5 minutes $(10000 \mathrm{rpm})$. The liquid phase was separated and precipitate was dried in a room temperature for about $1 \mathrm{hr}$. The obtained DNS preparation was dissolved in $100 \mu \mathrm{l}$ water and kept in $-20^{\circ} \mathrm{C}$ temperature. The DNS quality verification was executed with electrophoresis, comparing preparation with characterizing mass markers $\left(50 \mathrm{ng}^{-1} \mathrm{l}^{-1}\right)$ - Mass Ruler DNA Ladder Low Range \#SM0383 (Fermentas, Lithuania). Quality verification was executed in $1.7 \%$ agar culture medium with TAE buffer.

The DNS concentration was determined with Lambda spectrometer 25 Perkin Elmer.

From each flax variety DNS was portioned out and was tested with 12 primer pairs used in this method PCR (Polymerase Chain Reaction) which locus of products allele combinations characterize the variety suitability.

From 12 markers six LU002, LU013, LU021, LU023, LU31 and LU32 were used for further genotyping. The method of reiteration (SSR, Simple Sequence Repeats) of the simple sequences markers was used for a molecular passport system of flax varieties.

The each pair of genetic markers directed with primer marker $\mathrm{F}$ and was marked with one from fluorescing dyes: - 6-FAM; - NED; -HEX.

It enabled in the genotyping process to combine PCR products. All materials were stored in $20^{\circ} \mathrm{C}$ temperature and melted in small amounts shortly before use. Water for molecular biology was demineralised, purified from nucleases and protein impurities. To $10 \mathrm{nM}$ primer was join $50 \mu \mathrm{l}$ TE buffers, mixed carefully till fully dissolving. It was saved in darkness in $20^{\circ} \mathrm{C}$ temperature. To $2 \mu 1$ primer of storage solution was joined $98 \mu 1 \mathrm{TE}$ buffer.

In PCR reaction obtained DNS fragments analysed with DNS 3100-Avant Genetic Analyzer Both, using programme GeneMapper v. 4.0.

There were combined the obtained with PCR fragments each $0.7 \mu 1$ with different colours different (6-FAM, HEX, NED), added $0.8 \mu$ l GeneScan TM -350 ROX TM Size Standard and $8 \mu \mathrm{Hi}$-Di TM formamids, denatured in a special device in $95^{\circ} \mathrm{C}$ temperature for 5 minutes.

\section{Results and discussion}

The flax fibre quantity depends on the sowing period and the fertilization of flax plants. The fibre of flax and its quality depend on climate circumstances and selected variety.

For Latvian climate are common long summer days, which are often cloudy, and it promotes appearance of longer, thinner stems, from which a high-quality fibre and yield of good seed are obtained. Early flax sowing allows to obtained flax with more qualitative fibre. In Latvia 
fibre flax needs to be planted from May $5^{\text {th }}$ till May $20^{\text {th }}$, but the period for sowing of oil flax is the beginning of April [1].

In 2007-2009 the duration of vegetation period was determined for 92 flax accessions. Summarizing results after a vegetation period, flax accessions were divided in 2 groups: the early ones (vegetation period 75-80 days (75 accessions) and for the serotinous accessions vegetation period was 86 days (17 accessions). During the vegetation period the more frequently flax diseases were anthracnose (caused by Colletotrichum lini (Westerdijk) Tochinai), bacteriosis (caused by Clostridium (Bacillus) macerans Schard.), flax seedling wilt (caused by Fusarium oxysporum Schlechtend.) and blight (caused by Colletotrichum lini). The phytopatalogical observations of flax were executed during all vegetation period. Fusarium sp. was established on isolated flax plants of 14 accession ('5586', '3686', 'Blue di Riga', 'Vietejais 1', 'Riga Freis', 'Riga Vilmorin', 'Rigaer LIN 780/81', 'N5' , 'Altgauzen 18×99', 'Altgauzen 16×90'; 'Vietejais 3'; 'L 19-6/15-95', 'T31-40-94', 'Vega 2'). Clostridium macerans was established on isolated plants of 3 varieties ('Vega 2', 'Vietejais 4'; 'N 116').

The stability of plants' lodging during vegetation period was determined. The determination of lodging was done in accordance with a method of 10 grade system. In 2009 flax lodging was established in 5 varieties: 'Osupes 30', 'Rigaer LIN 748/82', 'Riga Freis', 'Rigaer 6/5', 'Rigar B'.

The obtained yield of straw is shown in Figure 1. The yield of flax straw of standard variety 'Vega 2' obtained in 2007 was $660 \mathrm{~g} \mathrm{~m}^{-2}$. In 2007 standard was exceeded only by 'S-64-17-93' (yield of straw $750 \mathrm{~g} \mathrm{~m}^{-2}$ ) and by accession 'L11-11/11-94' (yield of straw - $703 \mathrm{~g} \mathrm{~m}^{-2}$ ). In 2008 a higher yield of straw was obtained from varieties 'Priekulu 665' and 'Osupes 30'. In 2009 better straw yield was obtained from flax varieties 'Priekulu $665^{\prime}-753 \mathrm{~g} \mathrm{~m}^{-2}$ and accession 'T-36-26/4-8-94' - $837 \mathrm{~g} \mathrm{~m}^{-2}$.

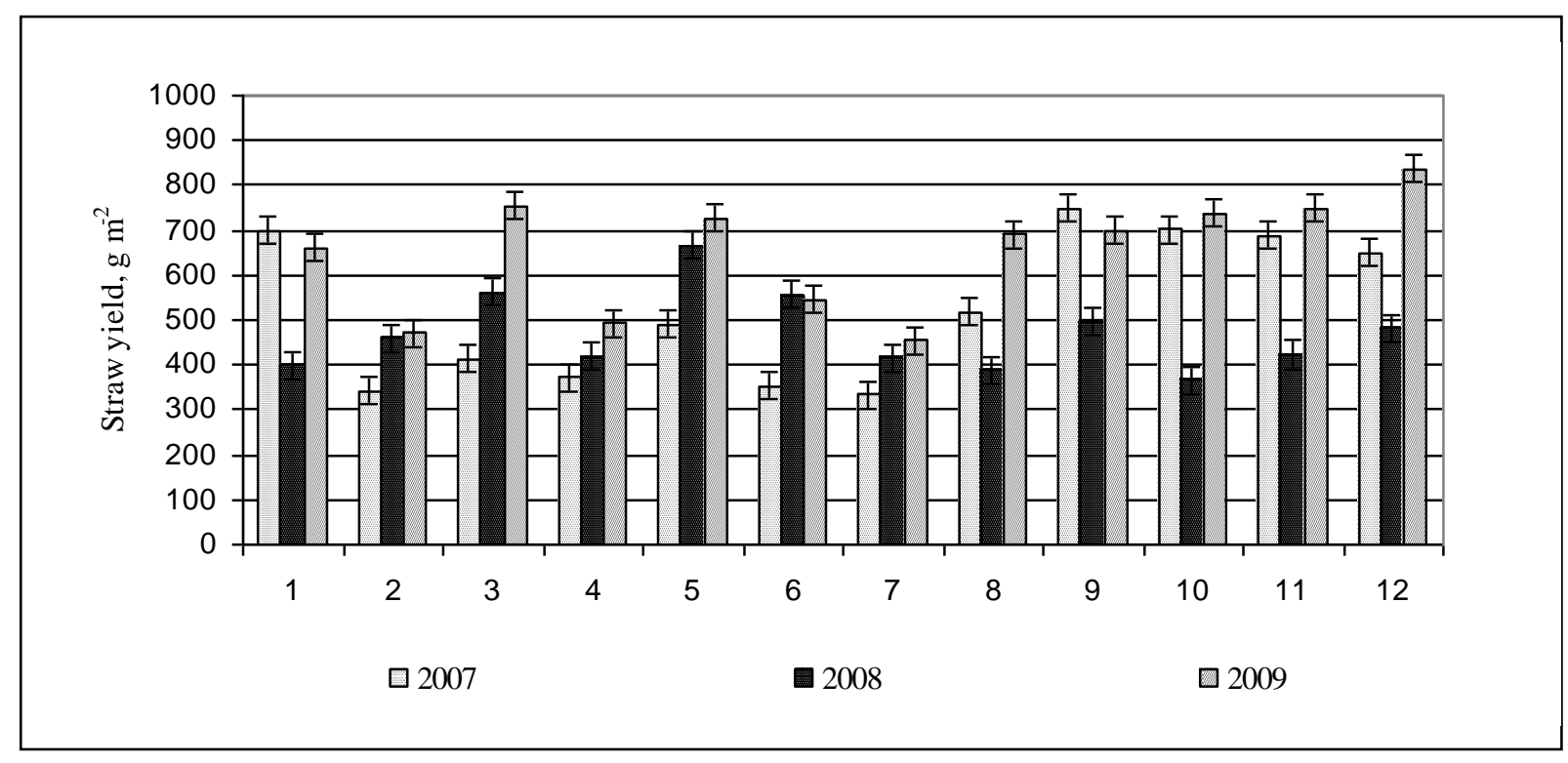

Fig.1. The yield of flax accession in 2007-2009

Names of varieties and accessions: 1 - 'Vega 2'; 2 - 'Blue di Riga'; 3 - 'Priekulu 665'; 4 - 'Riga Freis'; 5 - 'Osupes 30'; 6 - 'Vietejais 1'; 7 - 'Rigaer LIN 748/82' ; 8 - 'S-53/8-3-93'; 9 - 'S-64-17-93'; 10 - 'L1111/11-94'; 11 - 'L19 - 6/15', 12 - 'T-36-26/4-8-94' ; (n=92)

The average data of three years show, that some of flax varieties and accessions had higher seed yield than that of standard variety of 'Vega 2': 'Osupes 30 ' $-628 \mathrm{~g} \mathrm{~m}^{-2}$, 'S-64-17-93' $649 \mathrm{~g} \mathrm{~m}^{-2}$, 'L11-11/11-94' - $602 \mathrm{~g} \mathrm{~m}^{-2}$, 'L19 - 6/15' - $620 \mathrm{~g} \mathrm{~m}^{-2}$ and 'T-36-26/4-8-94' - $656 \mathrm{~g}$ $\mathrm{m}^{-2}$. In Latvian circumstances the straw yield of 3.3-7.5 $\mathrm{t} \mathrm{ha}^{-1}$ can be obtained. 


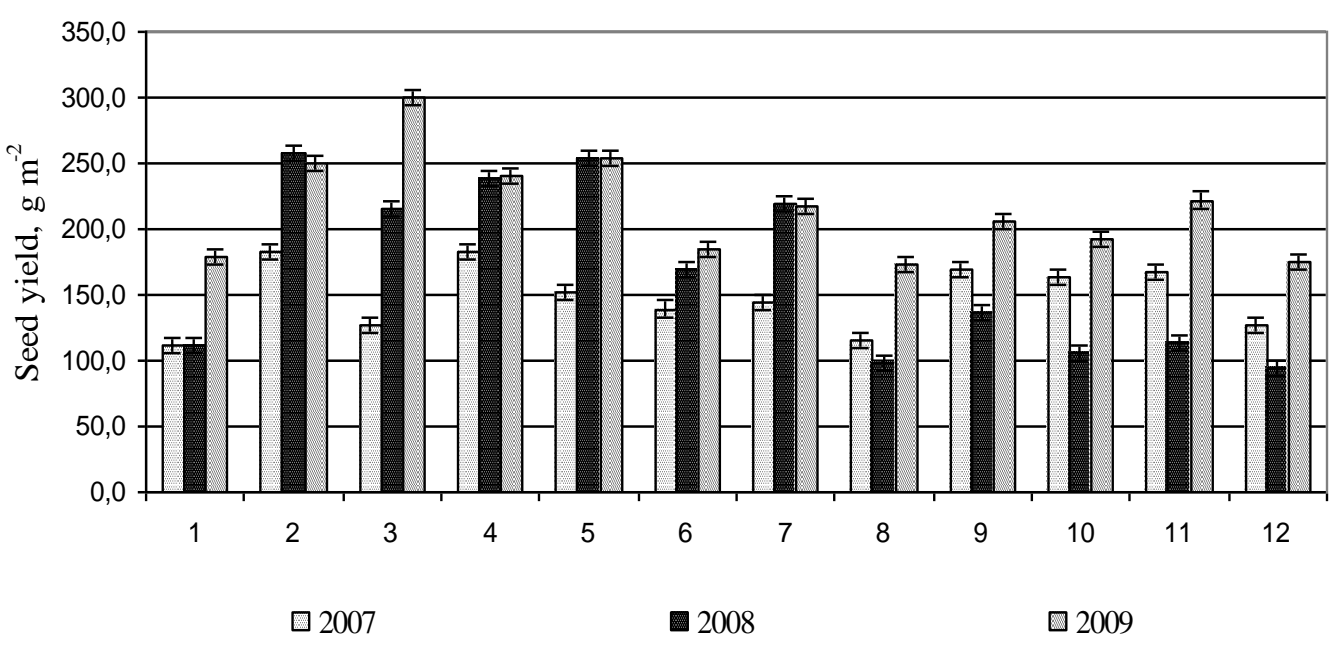

Fig.2. Seed yield of flax accession in 2007-2008

Names of flax varieties and accessions: 1 - 'Vega 2'; 2 - 'Blue di Riga'; 3 - 'Priekulu 665'; 4 - 'Riga Freis'; 5 - 'Osupes 30'; 6 - 'Vietejais 1'; 7 - 'Rigaer LIN 748/82' ; 8 - 'S-53/8-3-93'; 9 - 'S-64-17-93';10 'L11-11/11-94'; 11 - 'L19 - 6/15', 12 - 'T-36-26/4-8-94' (n=92)

Seed yield depends on many factors: amount of capsules from one plant, amount of seeds in a capsule and 1000 seed weight. In 2007-2009 the seeds of good quality from 54 accessions (59 $\%$ of all tested accessions) were obtained. These accessions had a higher seed yield than the standard 'Vega 2'. In 2009 yield of seed was 1.7-3.0 $\mathrm{t} \mathrm{ha}^{-1}$. In 2007 the highest yield of seed was obtained from 'Blue di Riga' - $182.3 \mathrm{~g} \mathrm{~m}^{-2}$ and 'Riga Freis' - $183.5 \mathrm{~g} \mathrm{~m}^{-2}$, in 2008 - from 'Osupes 30' (Figure 2). In 2009 the best yield of seed was obtained from varieties 'Priekulu $665^{\prime}-300.6 \mathrm{~g} \mathrm{~m}^{-2}$, 'Osupes 30 ' - 353.1 $\mathrm{g} \mathrm{m}^{-2}$, 'Blue di Riga' - $250.3 \mathrm{~g} \mathrm{~m}^{-2}$. The average of three years show that the best yield of seed was obtained from the fibre flax varieties 'Blue di Riga', 'Priekulu 665' and 'Riga Freis'.

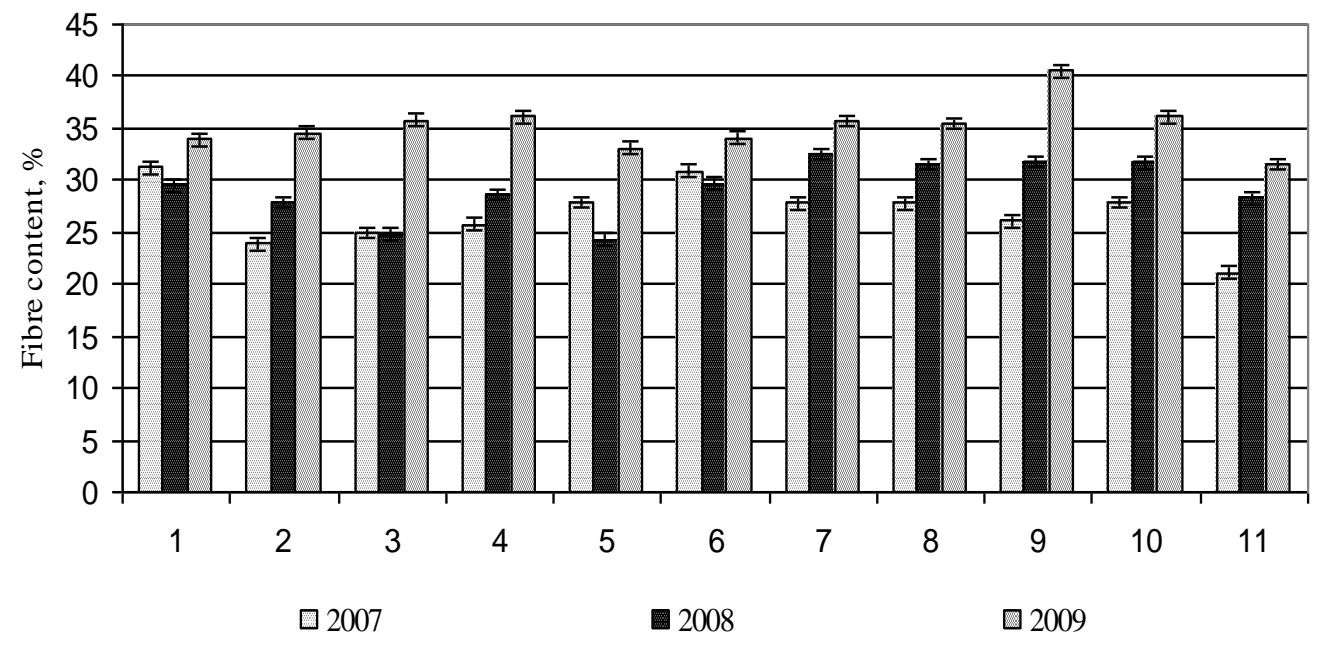

\section{Fig.3. Fibre content (\%) of flax accessions in 2007-2009}

Names of varieties and accessions: 1 - 'Vega 2'; 2 - 'Blue di Riga'; 3 - 'Priekulu 665'; 4 - 'Riga Freis'; 5 - 'Osupes 30'; 6 - 'Vietejais 1'; 7 - 'Rigaer LIN 748/82' ; 8 - 'S-53/8-3-93'; 9 - 'S-64-17-93'; 10 - 'L1111/11-94'; 11 - 'L19 - 6/15', 12 - 'T-36-26/4-8-94' ; (n=92) 
One of the main yields forming factor was an amount of seed in a capsule. The maximal amount of flax seeds in a capsule can be 10, but an amount of seeds in a capsule of fibre flax reared in Latvia can be from 7.7 to 9.8. The climatic circumstances of the year 2007 were favourable for the development of flax seeds. Seeds are influenced by the weather.

More they are influenced by the amount of rain during the vegetation period, a superfluous humidity lowers quality of seeds; they will be mat and flat. In our investigation the weather conditions had contributed to seed yield and quality of the seed ripening period in 2008. High quality seeds were obtained, they were brilliant and smooth. In 2007-2009 the weight of 1000 seeds was from 4.80 to $6.78 \mathrm{~g}$, and on average 5.79 grams. This pointer was exceeded by 29 accessions.

Flax fibre is formed during the rapid growth phase and during the formation of buds and stalk. To ensure good fibre, plants should be well provided with moisture. Fibre quality is negatively influenced also by a superfluous humidity amount; a flimsy fibre appears then. In 2007 the best content of fibre was found in fibre flax varieties 'Blue di Riga' $-31.2 \%$, '55833'-30.9\% and accession 'S-53/8-3-93' -27.8 \% 'S-64-17-93' - $27.8 \%$ and 'L23-26/397 ' $-27.9 \%$. In 2008 the best content of fibre was found in fibre flax varieties 'Blue di Riga' $29.5 \%$ and accession 'S-53/8-3-93'-32.5\%. In 2009 the best content of fibre was found in fibre flax varieties 'VN1'- 36.1\%, '5581'- $35.8 \%$ and accession 'T36-26/4-8' - 33.3 \%, 'L23$26 / 3-97$ ' $32.0 \%$. In 2009 the best content of fibre was found in fibre flax accession to be $31.1-40.5 \%$ - in the accessions, the best fibre content of the standard 'Vega 2' was $31.5 \%$. This pointer was exceeded by 63 accessions (68\% of all tested accessions). Higher fibre content can be obtained from the varieties 'Blue di Riga', and accession 'T-36-26/4-8-94' and 'L-26 -47/1 -97'.

The seeds of flax are rich in lipids (33-45\%), protein (18-33\%), fibre substance (28-35\%), mineral elements $(\sim 4 \%)$ and vitamins $[2,3]$. Oil content in linseeds depends on variety. Oil content in varieties of fibre flax reared in Latvia is 40.6-45 \% (Figure 3). From flax tested during three years, the largest oil content had the accessions of fibre flax 'Rigaer LIN 748/82', 'T 36-26/4-8-94' and 'L-19/15 -97'.

The DNS analysis was done 12 accessions of flax together with standard done (Figure 4.)

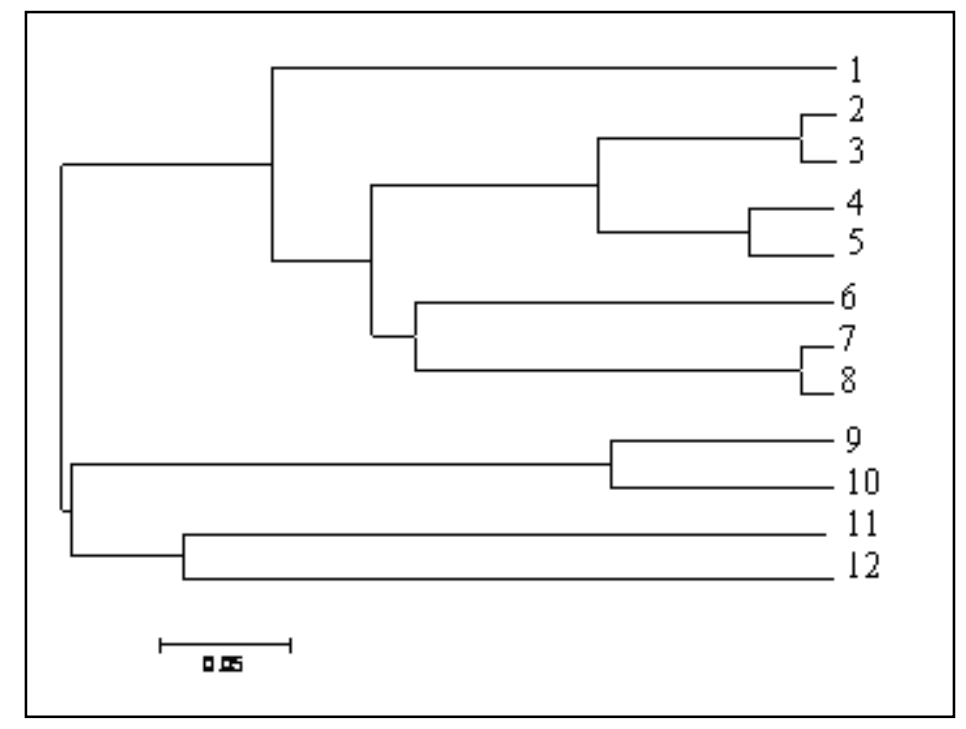

Fig.4. Origin of flax, dendrogramma after Shared-allele, UPGMA programme

Names of varieties and accessions: 1 - 'Rigaer LIN 748/82'; 2 -'S-53/8-3-93'; 3 - 'T36-26/4-8'; 4 'L19/6-15'; 5 -'Vega 2'; 6 - 'Vietejais 1'; 7 -'Blue di Riga'; 8 -'Riga Freis'; 9 - 'Osupes 30'; 10 - 'Priekulu 665'; 11 - 'L11-11/11'; 12 - 'S-64-17-93' 
With use of the LU002, LU013, LU021, LU023, LU31 and LU32 markers the diversity of 12 flax accessions was determined. With the distances 0.05 of the DNS fragments flax differed by two alleles. Flax accesions 'Osupes 30', 'Priekulu 665', 'Rigaer LIN 748/82', 'S 64-17-93' and 'Vietejais1' were heterozygote. The variety 'Blue di Riga' contained vegetable population, which had the lowest multiplicity (homozygous). But the largest diversity had accessions 'S64-17-93' and 'Vietejais 1'. Of origin dendrogrammas of 12 flax accessions were divided into two kinds, and the nearest cognation had accessions 'L11-11/11-97' and 'S64-17-97'. The varieties of flax 'Priekulu 665' and 'Osupes 30' were supposed to be closely related and had a better possibility to obtain large and a stable yield of seed.

\section{Conclusions}

According to the investigation of three years, the highest seed yield was obtained from flax plants of varieties 'Blue di Riga', 'Riga Freis', 'Osupes 30' and accessions 'L- 19/6-15 - 97' and 'L-11-11/11-94', but fibre flax 'Riger LIN 748/82' and accession 'T36-26/4-8-94' and 'L-19/15 -97 ' had the highest oil content.

The highest straw yield was obtained from the variety 'Osupes 30' and accessions 'S64-17-93', 'S 13/5 -7/3-93', 'K 47-17/11-6-95', but 'Blue di Riga', 'Vietējais 1' and accessions of flax 'T36 - 26/4-8-94', 'L -26 -47/1 -97' had the best content of fibre.

Following seven flax crop quality indicators (the technical stem length, yield of seed and straw, seed number per capsule, 1000 seed weight, fibre and oil content) the most suitable there were 5 varieties - 'Blue di Riga', 'Osupes 30', 'Riga Freis', 'Priekulu 665' and 'Vietejais 1', one line the 'Rigaer LIN 748/82' and 5 accessions - 'S-53/8-3-93', 'S-64-17-93', 'L1111/11-94', 'L19 - 6/15' and 'T-36-26/4-8-94'. The DNS analysis showed, that the closest relationship was established between accessions 'L11-11/11-97' and 'S64-17-97'. The largest diversity had accessions 'S64-17-93' and 'Vietejais 1'.

\section{Acknowledgements}

This publication has been prepared within the framework of the ESF Project „Attraction of human resources to the research of the renewable energy sources", Contract $\mathrm{Nr}$. 2009/0225/1DP/1.1.1.2.0/09/APIA/VIAA/ 129. I want to thank to forest researcher PhD Dainim Rungim, for his cooperation and assistance in the Genetic analysis of DNA. „Agriculture Science Center of Latgale” ltd, for organizing the trial.

\section{References}

1. Ivanovs S., Stramkale V. Flax cultivation and harvesting technology. Jelgava, 2001, p. 191. (In Latvian)

2. Morris D. Flax: A health and nutrition primer, Winnipeg: Flax Council of Canada, 2003, p. 11.

3. Liepiña A. Lini (Flax), Materia medica, 2, 2006, p. 27-30. (In Latvian).

4. Nandy S., Rowland G. Dual Purpose Flax (Linum usitatissimum L.) Improvement Using Anatomical and Molecular Approaches. 2008 International Conference on Flax and Other Bast Plants, 2008, p. 31-39.

5. Ranjzad M., Khayyami M., Hasanzadeh A. A Comparison of Important Physical and Chemical Characteristics of Linum usitatissimum Sub. Species. Pakistan Journal of Nutrition, 3, 2007, p. 238-240.

6. Stramkale V., Poiša L., Vikmane M., Stramkalis A., Komlajeva L. Oil flax breeding and application opportunity in Latvia. In: Economic development problems and solutions, International Scientific Conference No.2, Rezekne, 2008, p. 412-420. (In Latvian)

7. Stramkale V., Sulojeva J., Seržane R., Janševskis E., Gudriniece E. Flax - Prospects for fiber and oil crop production in Latvia. Environment. Technology. Resources, Rezekne, 2003, p. 251-257. (In Latvian)

8. Zelenin A.V., The genome of plants, Bulletin of the Russian Academy, 9, 2003, p. 797-806. (In Russian)

9. Zelenin A.V., Badajeva E.D. Molecular Biology. 35, 2001, p. 339-348. (In Russian)

10. Muravjenko O.V., Lemesh V.A., Samatadze et al. Comparison of the genomes of three closely related species of flax and their hybrids with chromosomal and molecular markers. Genetics, 39, 2003, p. 510-518. (In Russian)

11. Pen E. Bonanza for Plant Genomics, Science, No. 282, 1998, p. 652-654.

12. Williams J.G.K., Kubelik A.R., Livak K.J. et al. DNA polymorphisms amplified by arbitrary primers are useful as genetic markers, 1990, p. 6531-6535. 